\title{
Subsoil use payments: the experience of legal regulation in the Russian Federation*
}

\author{
Aleksandr A. Yalbulganov
}

For citation: Yalbulganov, Aleksandr A. 2018. Subsoil use payments: the experience of legal regulation in the Russian Federation. Pravovedenie 62 (4): 779-791.

https://doi.org/10.21638/spbu25.2018.412

Oil and gas revenues maintain a leading position in the structure of budget revenues. The variety of payments for the use of subsoil, regular public-legal payments of a non-tax nature enacted by the Law of the Russian Federation on Subsoil ("Subsoil Law"), occupy a special place. Based on an analysis of legislation, judicial practice and legal doctrine, the system of such payments established in the RF Law on Subsoil is examined from the point of view of their legal nature, the quality of legal regulation as well as fiscal significance. In connection with the discussion about the need to include non-tax payments in the text of the Tax Code of the Russian Federation and the scope of tax regulation, the author concludes that such inclusion is inappropriate. He explains his position with a number of objective reasons (factors), primarily the rental nature of payments for subsoil use. Currently, all these circumstances are duly taken into account in environmental legislation (nature resources legislation). The Subsoil Law only establishes minimum and maximum payment rates and determines them depending on the types of work and minerals. The specific rate-set is taking by the evolution coefficients, which are regularly adjusted by the Government of the Russian Federation. Regardless of the types of payments for the use of subsoil (tax or non-tax payments), correction coefficients provided for by the legislative body or established by-laws are applied, which are aimed at equalizing economic conditions for subsoil users. The author notes that non-tax and tax payments for subsoil use come from the same natural source - from the subsoil. Regardless of their legal nature, they are fiscal payments, revenues from the use of mineral resources at various stages and transferred to the budgets of the budget system of the Russian Federation. Therefore, with regard to regular payments, the fact of their inclusion in the system of taxes and fees of the Russian Federation is not essential, especially since the tax authorities are the administrators of these payments. An additional argument in favor of the fiscal nature of non-tax payments for the use of subsoil is the fact that the Environmental Law does not fix the environmental goals of payments, they are not targeted and do not go to any state extra-budgetary funds. The basis for payments for the use of subsoil is the principle of paid use of subsoil, which applies to all types of environmental management and has been expressed in all natural resource laws, most of which are codified acts. The author proposes to modernize one-off payments, fixing all the elements of such payments directly in the law, and not in adopted ad hoc legal acts of a regulatory nature.

Keywords: chargeability of subsoil use, payments for the use of subsoil, subsoil users, regular and one-off payments, production sharing agreements.

* The article was prepared within the framework of the Academic Fund Program at the National Research University Higher School of Economics (HSE University) in 2017-2018 (grant No. 17-01-0064) and within the framework of the Russian Academic Excellence Project "5-100".

Aleksandr A. Yalbulganov - Dr. Sci. in Law, Professor, School of Public Law, National Research University Higher School of Economics, 20, ul. Myasnitskaya, Moscow, 101000, Russian Federation; yalbulganov@hse.ru

( Санкт-Петербургский государственный университет, 2019 
Introduction. Currently, the Russian Federation has complex system of payments for the use of subsoil ${ }^{1}$. In the preamble of the Law of the Russian Federation as of February 21, 1992 No. 2395-12 "On Subsoil"2 (Subsoil Law), subsoil is defined as "part of the Earth's crust underlying the soil stratum and, in its absence, underlying the Earth surface and the bottom of bodies of water and watercourses, and extending to depths accessible to geological exploration and development". Art. 1.2. of the Subsoil Law stipulates that subsoil within the territory of the Russian Federation, including the subsoil domain and mineral resources contained therein, energy and other resources, shall be state property. The basis of the mechanism for realizing the right of state ownership of subsoil is the principle of the chargeability of subsoil use, which is a special legal tool based on the principle of rental relations. Payments for the use of subsoil are one of the main tools of the state's fiscal policy for levying revenues, generated as a result of the exploration and mining of the subsoil, for the state budget ${ }^{3}$.

The issue of the chargeability of subsoil use as a special legal instrument is assigned to an independent section (Section V "Subsoil Use Payments") of the Subsoil Law. According to art. 39, the system of subsoil use payments includes three separate types of payments:

1) one-off payments for the use of subsoil upon the onset of certain events stipulated by the license, including one-off payments made when changing the boundaries of subsoil plots allotted for use (one-off payments) (art. 40 of the Subsoil Law");

2) regular payments for the use of subsoil (regular payments) (art. 43 of the Subsoil Law);

3) a fee charged for participation in a tender (auction) (art. 42 of the Subsoil Law).

In addition to the above, art. 39 of the Subsoil Law specifies that subsoil users pay other taxes and fees established in accordance with the legislation of the Russian Federation on taxes and fees. The Mineral Resource Extraction Tax (MRET) was introduced in January 1, $2002^{4}$ and replaced three previous subsoil use payments: payment for subsoil use (royalties), fees for the regeneration of mineral resources and raw materials, and excises on oil and gas condensate. At present, the payers and other essential elements of the MRET as a federal tax are collected in one place and regulated legally in Chapter 26 of the Tax Code of the Russian Federation (TCRF).

This article addresses only payments for the use of subsoil that are established in the Subsoil Law along with the duty and procedure for their payments. The MRET and the legal mechanism for taxing mineral resource extraction are not examined, except

1 The notions "subsoil use payments" and "payments for the use of subsoil" are used in this article as identical and refer only to payments established by the Subsoil Law, i.e. they do not refer to the Mineral Resource Extraction Tax, regulated by the legislation of the Russian Federation on taxes and fees, and payments for performance of product sharing agreements. The legislator uses the concept "subsoil use" in the title of Section 5 and notion "for the use of subsoil" in the names of specific types of payments in the Subsoil Law.

2 The Law of the Russian Federation as of February 21, 1992 No. 2395-12 "On Subsoil" // Sobranie zakonodatel'stva Rossiiskoi Federatsii. 1995. No. 10. Art. 823.

3 The design of payments for the use of subsoil was also studied in the works of E. A. Sutkevich. See more in detail: Sutkevich E. A.: 1) Payments for the use of subsoil as a form of mandatory public-legal payments similar to taxes and fees // Reformi i pravo. 2015. No. 1. P. 10-13; 2) The legal nature of payments for the use of subsoil in the Russian Federation // Reformi i pravo. 2012. No. 3. P.50-57 and others.

4 See: Federal Law as of August 8, 2001. No. 126-FZ "On Amendments and Additions to Part Two of the Tax Code of the Russian Federation and Certain Other Acts of the Legislation of the Russian Federation, and on the Repeal of Certain Acts of the Legislation of the Russian Federation" // Sobranie zakonodatel'stva Rossiiskoi Federatsii. 2001. No. 33 (part 1). Art. 2174. 
for the specifics of the use of certain elements of the MRET in calculating and paying one-off payments for the use of subsoil.

1. Financial instruments for levying of revenue from the use of subsoil. The role of the state in the establishment and settlement of payments for the use of subsoil may be different and depend first of all on the state's applied legal forms granting subsoil for use to the subjects of entrepreneurship. For example, bonuses, rentals and royalties ${ }^{5}$ in most mining countries are non-tax rent distribution instruments, as they are subject to regulation in special contracts in the field of subsoil use. For instance, in almost all states which continue to use one-off payments - bonuses (including such types as signing bonus, bonus on commercial discovery or achieving a certain level of production) are attributed to payments that are usually set as a result of negotiations and fixed in agreements of various types: in terms of concession agreements (e. g. Brazil, Egypt, Nigeria, Oman, Thailand), the lease of subsoil plots (e.g. the USA, Canada), or production sharing agreements (e. g. Angola, Cameroon, China, Denmark, Uganda, Vietnam, the Netherlands, the Philippines). Rental (surface payment) is most often a fee in the form of rent for a subsoil plot and is established in a mining lease for the right to conduct search and exploration work, depending on the size of the area, the type of mineral, lease term, the degree of exploration of the subsoil area, etc. Royalties are non-tax payments that are established depending on the volume of minerals extracted by the enterprise or their value, which is defined as the payment for a share of the production or profit paid to the owner6.

Under the Subsoil Law, subsoil plots may be granted only for use, and on the basis of a special state permit in the form of a license, where the conditions for the use of subsoil, including payment terms, are an integral appendix to the license, and are not an independent document.

However, in doctrine and in practice, there are opinions on the civil-legal nature of subsoil use relations certified by a license. Some researchers and practicing lawyers consider the conditions of subsoil use (a license agreement) as a civil law transaction. This approach is also found in court decisions ${ }^{7}$.

The author of this article adheres to the position of the public-legal nature of subsoil use relations, and justifies the existence of precisely the public-legal and financial-legal nature of one-off and regular payments for the use of subsoil.

In this case, the right of the state to derive rental income through the establishment and collection of special mandatory payments from subsoil users to the budget arises not only from the right of the state to ownership of natural resources in their natural state, but also from the absolute power of the state to determine the revenue sources of its financial resources without being dependent on the will of payers or other subjects of law, which is known in the theory of tax law as the fiscal sovereignty of the state ${ }^{8}$. Tax cannot be established, changed or abolished otherwise than by law; this legal principle

5 The analogue of royalties in Russia is the MRET, the analogue of bonuses - one-off payments for the use of subsoil, the analogue of rentals - regular payments for the use of subsoil.

6 Dudikov M. V., Klyukin B. D., Melekhin E. S. State regulation of subsoil use in the Russian Federation: historical aspect and foreign experience. M., 2011. P. 135.

7 For example, in the case file A40-23799 / 10-65-146, the Supreme Arbitration Court of the Russian Federation concluded that the license agreement is a transaction aimed at establishing the rights and obligations of the parties related to granting the right to use the subsoil; in the ruling of the Supreme Arbitration Court of the Russian Federation as of October 18, 2012, in case No. A50-12973 / 2011, it is directly stated that the reason for the occurrence of unjust enrichment in the form of a one-off payment amount is the court's recognition of an invalid auction, which resulted in the right to use subsoil and etc.

8 See: Orlov M. Y. Tax as a form of reasonable limitation of fiscal sovereignty of the state // Finansovoe pravo. 2006. No. 2. P. 18-23. 
of tax law is fixed in the text of most state constitutions ${ }^{9}$. The obligatory legislative establishment of tax may be due to the fact that, in essence, tax is the withdrawal from the taxpayer a part of their property, the right to which in many states, including the Russian Federation, is protected by the Constitution.

This confirms the public-legal nature of payments for the use of subsoil, the size and order of the payments not being subject to an agreement between the parties, de facto, is in no way connected with civil-legal obligations.

To a certain extent, production sharing agreements are special public contracts in the field of subsoil use, which provide for the possibility of subsoil use in the Russian Federation on the terms of a special agreement between the Russian Federation and the investor.

In accordance with art. 39 of the Subsoil Law, it is determined that subsoil users acting as a party to production sharing agreements (PSA) are also payers of subsoil use payments in accordance with the legislation of the Russian Federation ${ }^{10}$. The main distinctive feature is that the procedure, amount and conditions for the collection of subsoil use payments in the implementation of PSA are established by these agreements in accordance with the legislation of the Russian Federation in force at the date of signing of the agreement. In other words, the conditions on the amount and procedure for subsoil use payments at the conclusion of a PSA may be subject to an agreement between the parties, which makes it a special type of public agreement which includes elements of permissive rule (dispositivity), but it is in line with the norms of the legislation of the Russian Federation in force at the time of signing of the PSA.

Subsoil use payments as compulsory payments of a public nature constitute an independent legal form of one of the sources of budget revenue and, accordingly, one of the sources of the coverage of the budget expenditures.

Even in studies of financial law of the Imperial era, regalias, along with duties, had much in common with taxes, which also brought large revenues to the treasury, representing a transitional stage from private economic revenues of the state to taxes. Regalia as one of the types of sources of public revenues according to I. I. Yanjul ${ }^{11}$ occupies a middle position between two extensive types of sources of state revenue: private law sources (domains) and public law revenues (taxes) ${ }^{12}$. At the same time, with regard to the mining regalia I. I. Yanzhul especially noted its fiscal significance and goals, which brought the mining regalia closer to taxes. The state itself exploits the subsoil of the land or cedes it to private individuals, and "for this permission of free mining of minerals it levies special charges on them; it is obvious this charges are the result of recognition of the regality of mining".

Thus, at the present time, mountain regalia, if it is understood in a broad sense, both as state participation in mining and as the establishment of mandatory payments to the budget, manifests itself mainly through the establishment of tax and non-tax instruments for the extraction of mining rent. At the expense of state funds, only work on regional geological study of the subsoil is conducted.

9 Kozyrin A. N. The tax law of foreign countries: questions of theory and practice. M., 1993. P. 77. See also: Kozyrin A. N. Legislation in Tax Law: principles of lawmaking procedures // Reformi i pravo. 2015. No. 3. P. 3-13.

10 It is noteworthy that the legislator used foreign denominations "bonus" - for one-off payments and "rentals" - for regular payments only in art. 13 of the Federal Law "On Production Sharing Agreements", not including them in the Subsoil Law.

11 Regalias in the Russian financial law tradition are commercial sources of income, which the state used primarily or exclusively for itself, not allowing or significantly limiting private competition. See: Yanzhul I. Basic Principles of Financial Science: The Study of Government Income. M., 2002 (Golden Pages of Russian Financial Law; T. 3). P. 55, 137.

12 See: Ibid. P. 55, 138. 
One-time and regular payments for the use of subsoil have a rental nature; by their legal nature, they represent remuneration paid by the subsoil user to the subsoil owner - the state in connection with the provision of subsoil plots for use ${ }^{13}$.

2. Regular payments. Regular payments for the use of subsoil by their nature and legal characteristics are very similar to taxes. The main aim of levying regular payments is to stimulate subsoil users to properly perform licensing duties in terms of carrying out geological exploration works, as well as the quick commissioning of the field for commercial operation and the beginning of mining operations.

Regular payments for the use of subsoil are mandatory public-legal payments calculated by a specially authorized federal public authority and are one of the mandatory conditions for subsoil use in a licensed subsoil plot. Regular payments are paid in connection with the implementation of geological exploration or the construction and operation of underground structures within the boundaries of the area of the subsoil provided for use and are intended to encourage the subsoil user to properly fulfil the conditions for the use of subsoil. Regular payments are made by legal entities and individual entrepreneurs recognized as subsoil users in accordance with the established procedure; in this connection the obligation to timely and correctly make appropriate payments arises from the moment of state registration of a license for subsoil use.

Regular payments for the use of subsoil are similar to taxes in their legal characteristics, the content of legal constructions, the functions performed and the place occupied in budget revenues. Regular payments are characterized by signs that are characteristic of taxes and derive from their legal definition, which is contained in p. 1, art. 8 of the TCRF. In particular, regular payments are mandatory payments, established by art. 43 of the Subsoil Law. Their payment is individually non-reciprocal, since it does not legally lead to the emergence of a corresponding obligation for the state or a counter obligation to perform a legally significant act in favour of the payer (the right to use the subsoil plot has already been granted). Regular payments by analogy with taxes are a form of alienation of monetary funds belonging to persons recognized as users of subsoil, on the right of ownership (or other property right), and paid for the financial support of the activities of the state and municipal entities, incoming to the budgetary system of the country as a tax type revenue.

The systematic failure to make regular payments for the use of subsoil may also be regarded by the licensing authority as a violation of the essential terms of the license, leading to an early termination of the right to use the subsoil. Other sanctions with respect to regular payments for the use of subsoil are not provided in the current legislation.

The legal basis for levying regular payments for the use of subsoil is the Subsoil Law (art. 43) (4 $^{14}$ and the Order of the Ministry of Natural Resources No. 134 as of March 7, 2014 "On Approving the Procedure for Determining Specific Sizes of Rates for Regular Payments for the Use of Subsoil".

13 Yalbulganov $A$. On the issue of the transformation of the system of taxes and fees of the Russian Federation // Finansovoe pravo. 2011. No. 7. P. 29-36.

14 Paragraph 3 of Article 43 of the Subsoil Law has been challenged regarding its constitutionality. The Constitutional Court of the Russian Federation indicated that the procedure for calculating and paying regular payments for the use of subsoil resources, established by the federal legislator in the first paragraph of clause 4 of article 43 of the Law of the Russian Federation "On Subsoil", is cannot be considered as violating the applicant's constitutional rights in the aspect indicated in the complaint. See for more: Decision of the Constitutional Court of the Russian Federation No. 2314-O as of October 06, 2015 "On refusal to accept complaint of the joint-stock company 'Orenburgneft' for violation of constitutional rights and freedoms in paragraph 1 of clause 4 of article 43 of the Law of the Russian Federation On Subsoil Resources". 
The size of regular payments for the use of subsoil is determined depending on the economic and geographical conditions, the size of the subsurface area, the type of mineral, the duration of the work, the degree of geological study of the territory and the degree of the risk.

The legislator thereby takes into account the rental nature of the regular payment. The Law on Subsoil establishes only the minimum and maximum rates and determines them depending on the types of work and minerals. The specific rates are set taking into account the correction factors, the calculation formula is provided by the Order of the Ministry of Natural Resources No. 134 as of March 7, 2014 "On Approving the Procedure for Determining Specific Sizes of Rates for Regular Payments for the Use of Subsoil"15. Regardless of the types of payments for the use of subsoil (tax or non-tax payments), corrective factors established by the legislative body are applied, which are aimed at equalizing economic conditions for subsoil users.

The license defines the purpose, types, scope and terms of work, as well as the stages of carrying out the specified works, including conditions on the mandatory introduction of the amounts of regular payments at certain rates.

In such a manner, the legal fact of the emergence of the right to use a subsoil plot (from the moment of the state registration of a license) not only determines the duty of the subsoil user to subsequently make regular payments, but also generates it regardless of the direct performance of works on the subsoil plot (with the exception of the obligation to make regular payments for the exploration of minerals, which arises from the moment when the reserves of the relevant minerals are put on the balance sheet).

The parameter for measuring the regular payments is the unit of measurement of the area of the subsoil plot and the unit of mass or volume that determines the amount of minerals stored in the underground structure, which predetermines the differences in the methods of formation of the imposable base.

The most important element of the legal design of a mandatory public-legal payment and one of the parameters of its imposition is the procedure for calculation. In art. 43 of the Subsoil Law it is not legally fixed. Due to this unsatisfactory legislative regulation of regular payment, the enforcement process is significantly complicated both for payers and for the tax authorities, who are the payment administrators. The user of the subsoil can calculate the amount of the regular payment only by filling out the form for calculating regular payments for the use of subsoil, guided by the procedure for filing.

The procedure for calculating regular payments as an independent element of imposition is derived on the basis of an analysis of the provisions of p. 5, 6 and 7 of the Procedure for Filling the Calculation of Regular Payments. When the user conducts the work for the purposes of prospecting, the evaluation and exploration of mineral deposits, the payment amount is calculated as the product of the rate set in the appendix to the license and the amount of the imposition base (in the form of an imposable area of a licensed subsoil plot). When the subsoil user constructs and operates underground constructions, the payment amount is calculated as the product of the rate (corresponding to the type of mineral to be stored) and the amount of the imposition base (in the form of the amount of minerals to be stored and specified in the draft documentation for the construction and operation of the underground structure).

Thus, despite the predominantly tax-like nature of regular payments, most mechanisms and guarantees for protecting the rights and interests of taxpayers do not apply

${ }^{15}$ See also: Resolution of the Government of the Russian Federation No. 249 as of April 28, 2003 (ed. April 22, 2009) "On the procedure and conditions for charging regular payments for the use of subsoil from subsoil users searching and exploring deposits on the continental shelf of the Russian Federation and in the exclusive economic zone of the Russian Federation, as well as outside the Russian Federation in the territories under the jurisdiction of the Russian Federation". 
to subsoil users. Mostly, these are the mechanisms that facilitate the proper fulfilment of the obligation to make regular payments (both the substantive rules and the procedural aspects of their implementation), including the moment of origination, the change and termination of the duty, the specifics of its execution, the establishment and use of benefits, any deferral of payment, the offset and return of overpaid money, measures of forced levying.

The legal formalization of any public monetary levies should be based on fixing the main parameters for calculating the respective payments. The legislator should strive to regulate as accurately as possible all the mandatory elements of making regular payments and their content, in particular the object of imposition and the procedure for the formation of an imposable base, which directly affect the final size of the alienated monetary amounts of the subsoil users.

The inclusion of regular payments for the use of subsoil in the system of taxes and fees would significantly streamline the collection and payment procedure, extending to the mechanism for their payment measures more inherent to mandatory fiscal payments of financial and legal duty, and making the payment order more understandable and accessible to both the supervisory bodies and the payers (an example is the MRET and the fee for issuing a license which was recently transferred to the state duty). Such a law would guarantee the protection of the constitutional rights of each subsoil use payer ${ }^{16}$.

3. One-off payments. According to art. 40 of the Subsoil Law, subsoil users, who have received the right to use subsoil, make one-off payments for the use of subsoil upon the onset of certain events stipulated by the license.

The starting amount of one-off payments for the use of subsoil is set at a rate of at least $10 \%$ of the amount of the MRET in relation to the average annual capacity of the extracting organization, with the exception of one-off payments for the use of subsoil established with respect to oil and (or) gas condensate. The starting amounts of oneoff payments for the use of subsoil established for oil and (or) gas condensate are set at a rate of not less than $5 \%$ of the value of the MRET in relation to the average annual capacity of the producing organization for the oil and (or) gas condensate respectively.

The starting amount of one-off payments for the use of subsoil may be established as the amount of this person's expenses for the search and assessment of such a mineral deposit. This rule is valid only for the provision of an auction for the right to use a subsoil plot of federal significance containing a mineral deposit that was discovered in the course of geological exploration by a legal entity with the participation of foreign investors or a foreign investor, in respect of which the Government of the Russian Federation decided to refuse to grant the right to use this subsoil plot for exploration and the production of minerals.

Currently, the starting amount of one-off payments is mandatorily calculated by the licensing authority and is determined for each subsoil plot to be used and fixed in a license for subsoil use, indicating the order and terms of payment for the license holder.

The methodology for calculating the starting amount of one-off payments for the use of subsoil is established by Order No. 232 of the Russian Ministry of Natural Resources as of September 30, 2008 (Edited on December 06, 2017) "On the Approval of the Methodology for Determining the Starting Amount of a One-off Payment for the Use of Subsoil".

The final sizes of one-off payments for the use of subsoil are established by the results of a tender or auction and fixed in a license for subsoil use.

If the boundaries of the subsoil plots granted for use are changed, or when changes are made to the license in terms of determining the possibility of mining associated

\footnotetext{
${ }^{16}$ See in detail: Yalbulganov A. A. Op. cit.
} 
minerals, a one-off payment is paid by the subsoil user in the amount determined in accordance with the procedure established by the Government of the Russian Federation.

It is not allowed to establish in the license the amount of one-off payments for the use of subsoil below the conditions set by the tender or auction (or each of these payments) lower than those declared in the winner's bids.

A one-off payment is made under the procedure established in the license for the use of subsoil. It can be paid in instalments in the order established by the Government of the Russian Federation (see Decree of the Government of the RF No. 802 as of August 6, 2015 "On the terms and procedure on instalments of a one-off payment for the use of subsoil upon the onset of certain events stipulated by the license").

The amount of one-off payments for the use of subsoil, and the procedure for their payment when implementing production sharing agreements are established in the production sharing agreement.

One-off payments for the use of subsoil upon the onset of certain events stipulated by the license shall be paid to the federal budget and the budgets of the subjects of the Russian Federation in accordance with the budget legislation of the Russian Federation.

In the event of termination, including early termination, of the right of the use of subsoil, one-off payments paid by subsoil users are not refunded.According to the name of the payments, events that signify the moment of payment should be stipulated in the license. Such events can be the signing of an agreement, the discovery of a deposit, the beginning of its development, the achievement of a certain level of production. With this approach, these events can occur at any stage of the exploration process: at the stage of the search and evaluation of the deposit or at the stage of the prospecting and mining of natural resources ${ }^{17}$.

The basis for payment of one-off payments (the object of payment) should also be established at the level of the Subsoil Law, and not in the license, despite the wording in the denomination of one-off payments "upon the onset of certain events stipulated by the license". At present, depending on the basis of the payment, it is possible to distinguish two types of one-off payments: those that are paid when granting the right to use subsoil and those that are paid when the boundaries of subsoil areas increase ("in the event of allotment of land"). In addition, one-off payments for the use of subsoil are divided into two large groups, depending on the approach of granting the right to use subsoil: one is one-off payments for the use of subsoil which are paid for the right obtained as a result of tenders (auctions) and another is one-off payments for the use of subsoil that are paid for the right obtained without tenders (auctions). These two groups of payments have separate regulatory methods for their calculation (one approved at the level of the Ministry of Natural Resources of the Russian Federation, the other at the level of the resolution of the Government of the Russian Federation).

As indicated above, according to part 5 of art. 40 of the Subsoil Law, payment of one-off payments is made under the procedure established in the license for the use of subsoil.

The subsoil user, fulfilling the obligation to make one-off payments, should be guided first of all by the provisions of the individual legal act - the license for the right to use a subsoil plot, rather than the law, as a number of significant (mandatory) elements of their payment (final size, order and terms of payment), addressed to the payer, are set at the license level.

Economists studying the mechanisms for calculating one-off payments for the use of subsoil have not reached a consensus on the validity and effectiveness of the existing methods for the calculation of one-off payments. On one hand, there is a problem of

17 See: Perchik A. I. Taxation of oil and gas production. Pravo. Ekonomika. M., 2004. P. 222. 
the understatement of one-off payments, which can arise due to the vagueness of the legal formulations of a number of important concepts ${ }^{18}$. This kind of understatement unreasonably leads to a reduction in the amount of revenues to the country's budget. According to some estimates, the understated rental income of the country is $\$ 40-45$ billion $^{19}$. The reasons for the lack of objectivity in calculating one-off payments include the issue of the correlation between subsoil legislation and the legislation on taxes and fees in terms of regulating the taxation of mineral resource extraction. The basis for calculating one-off payments uses an approach which takes into account the proceeds from the future mining of minerals in the subsoil plots.

On the other hand, economists note the unjustifiably high starting amount of oneoff payments, which is one of the main reasons for the lack of interest from oil companies in the subsoil plots at auctions. The size of the minimum one-off payment is differentiated depending on the site placed at auction - the search site with predicted or prospective resources or a site with identified reserves. However, the minimum starting amount of the one-off payment calculated by the regulatory method does not differentiate depending on the type of use and the purpose of the site allocation (for searching and evaluating by geological examination or for exploration and production). Hence the cost of the average reserves and resources on the one-off payment is the same both in the search sites and in the fields with identified reserves. At the same time, risks, both geological and financial, are incomparable between search sites and sites provided for exploration.

Consequently, one-off payments for the use of subsoil are in fact single payments for obtaining the right to work on a subsoil plot corresponding to the types of subsoil use that may result in certain geological information on mineral reserves which confirm the possibility of subsequent extraction at the field.

One-off payments for the use of subsoil are directed for levying the mining rent, and not to compensate the state's expenses in the absence of any actions on the part of the state in favour of subsoil users, so they cannot have a compensatory nature. The main parameter for calculating the minimum value of one-off payments is the average annual capacity of the extracting organization (or the average annual extraction of mineral resources), which is calculated taking into account the mineral resource deposits and the forecast mineral resources that are held in the subsoil plot at the time of its use and that are transferred to higher categories using special formulas.

Thus, the amount of the minimum one-off payment is proportionate to the average revenue value which can potentially be obtained after the realization of the average annual amount of minerals extracted, rather than the cost of the state's expenses in

18 See: Denisov M. N., Lazarev V. N. On the procedure for determining the starting size of a one-off payment for the use of subsoil // Mineralnie Resursi Rossii. Ekonomika i Upravlenie. 2011. No. 2. P.41; Bogdanov D.S. Calculation of the sizes of one-off payments for the right to use subsoil plots provided without tenders and auctions // Neft, Gaz i Pravo. 2009. No. 5. P. 27; Bogdanov D. S., Fionina N. P. Different approaches of substantiating the size of the initial payment for the right to use subsoil // Neft, Gaz i Pravo. 2008. No. 5. P. 23.

19 See: Lvov D. S. Perspectives of Long-Term Social and Economic Development of Russia // Vestnik Rossiyskoy Akademii Nauk. 2003. T.73, no. 8. P.675-697. - Revenues from non-tax payments for the use of subsoil in 2015 amounted to $40,802,569.5$ rubles, of which $40,109,865.7$ were revenues from one-time payments for the use of subsoil upon the occurrence of events specified in the license for the subsoil use in the Russian Federation. The remaining amount is accounted for revenues from other types of payments for the use of subsoil - fees for participating in a tender (auction) for the right to use subsoil plots, etc. Income from regular payments for subsoil use is taken into account in revenues from the tax on the extraction of commercial minerals, with the exception of regular payments for the extraction of minerals (royalties) in the implementation of production sharing agreements (Federal Law No. 377-FZ as of October 31, 2016, "On the execution of the federal budget for 2015" // Sobranie zakonodatel'stva Rossiiskoi Federatsii. 2016. No. 45. St. 6196). 
connection with the provision of subsoil plot for use, including the costs of regional geological subsoil exploration work. It is economically inexpedient for the state to independently explore mineral deposits.

Further, one-off payments, like regular payments, are paid once the right to subsoil use is granted, that is, after the state registration of the license.

On the basis of the above, the question arises as to whether the individual remuneration of a public-legal payment is always confirmed by its purpose as compensation for state expenses for the commission by authorized bodies in favour of a subsoil user of any legally significant or other actions, including the granting of special rights or the issuance of a license.

Neither one-off nor regular payments for the use of subsoil in their essence are levies in their legal and doctrinal understanding, since the one-off and regular payments are not related to the commission by authorized bodies in favour of the subsoil user of any legally significant or other actions, including the granting of special rights or the issuance of a license. When the obligation to make one-off and regular payments arises, the payer is already the owner of the license, i.e., the user of the subsoil.

One-off payments for the use of subsoil are an independent variety of mandatory public-legal payments paid by subsoil users for the right to use the subsoil plot in accordance with the purpose and types of work under the license and form a separate type of non-tax revenue.

Non-payment of one-off payments for the use of subsoil is secured by special measures of state coercion established in the license, in the form of the termination of the right to use subsoil according to p. 3 part 1 of art. 20 of the Subsoil Law, or by administrative liability (the imposition of a fine), but without the collection of arrears and without application of financial and legal measures (accrual and collection of surcharges).

In order to improve the legal regulation of the payment of one-off payments for the use of subsoil, it is necessary to legislatively define the objects for imposition of one-off payments and the procedure for calculating them, and to determine those elements of one-off payments which can be established at the level of subordinate regulatory legal acts and at the level of an individually executive acts - licenses for the use of subsoil.

It is necessary to understand the difference between one-off payments for the use of subsoil under Russian law from foreign analogues (bonuses), which, as a rule, are one of the terms of the parties' agreement (concession or special contract) and are established during the negotiation process. In such special contracts, the obligation to pay bonuses may not be provided for at all.

However, in the current Russian legislation on subsoil, a concession (or contract) form of regulation of subsoil use is not provided. Despite their "concession" origin under the legislation, one-off and regular payments for the use of subsoil are not concessionary, since the conditions for their payment are established in a special state permit - a license - and not in a contract.

In the issue of the proper legal determination of payments for the use of subsoil, the criteria for the legality of their establishment should be understood as the establishment of payers and the elements necessary for the calculation of payments in the Subsoil Law. In particular, it is necessary to plainly define the objects for the imposition of one-off payments and the procedure for calculating them and to determine those elements of one-off payments which can be established at the level of subordinate regulatory legal acts and at the level of an individually executive act - a license for the use of subsoil.

The Subsoil Law should only identify the Government of the Russian Federation as the supreme executive body having the right to specify the content of these elements 
through the adoption of its own regulatory legal acts. However, at the present time, in addition to the Government of the Russian Federation, a federal body for the management of the state subsoil fund, which performs functions on regulatory and legal regulation of subsoil use relations, represented by the Russian Ministry of Natural Resources is also entitled to exercise legal regulation of certain issues relating to the calculation and payment of subsoil use payments. It is also necessary to develop a legal and independent mechanism for calculating the minimum value of a one-off payment for the use of subsoil without reference to the legislation of the Russian Federation on taxes and fees that regulate the taxation of mineral resources extraction.

Conclusion. The hypothesis of this article, which presupposes an indispensable change in the status of non-tax payments for the use of subsoil, especially the regular payment for the use of subsoil, into tax payments, does not find its confirmation. Such non-tax and tax payments derive from one natural source - the subsoil. Regardless of their legal nature they are fiscal payments, revenues from the use of subsoil at different stages which are coming into the budgets of the budget system of the Russian Federation. Therefore, with regard to, for example, the regular payment it is not important if they are embodied in the system of taxes and fees of the Russian Federation or not, especially since the tax authorities are administrators of this payments. Additional arguments in favor of the fiscal nature of non-tax payments for the use of subsoil are also the fact that the Subsoil Law does not set forth environmental goals for payments, they are not earmarked and do not come into any state extra-budgetary funds ${ }^{20}$. Underlying the payments for the use of subsoil is the "user-pays" principle, which is used for all types of environmental management and has been enshrined in all natural resource laws, most of which are codified acts ${ }^{21}$. The manifestation of "user-pays" principle in two ways (through the establishment of payments for environmental usage and payment for negative impact) in the legislation of the Russian Federation seems to be non-accidental. Payments for environmental usage in its content correspond to the characteristics of rental payments, while payment for negative impact, in essence, has the greatest similarity to the environmental tax of many foreign countries, i.e. such public-law payment, the direct functional purpose of which is to prevent (mitigate) the negative impact of human activities on the environment.

It seems possible to attribute the following to the specific features of non-tax payments for the use of subsoil: the determination of the amounts (specific rates) of payments is carried out by a specially authorized body on the basis of a normative approved method of calculation; individual character of determination (fixing) of particular elements of payments in a license; payers are persons who are users of subsoil; payment is provided by special state constraint measures in the form of termination of the granted right to use subsoil, by revoking a license.

20 Many Russian researchers indicate that the scope of subsoil use is the most significant from a fiscal point of view. See more: Baygozin K. I. Issues of taxation and licensing of subsoil use in the practice of constitutional justice // Sud'ia. 2018. No. 6. P. 9-13; Kadomtseva A. E. The legal nature of one-time and regular payments for the use of subsurface resources under Russian law // Zakony Rossii: opyt, analiz, praktika. 2013. No. 12. P.95-98.

21 The concept of organizing the rational use of natural resources and the effectiveness of legal mechanisms for the protection of the environment was developed in the USSR by well-known law scientists such as O.S. Kolbasov, V. V. Petrov and others, and the principle of payment for environmental usage (as a derivative of the well-known principle "polluter pays principle" that has been consolidated in some international documents) is affected in the works of modern Russian scientists, who represent both environmental law (S. Bogolyubov, T. Petrova, M. Ponomarev and others) and financial law (V. Zaripov, A. Kozyrin, S. Pepelyaev, N. Sheveleva and others). 


\title{
References
}

Baygozin, Konstantin I. 2018. Issues of taxation and licensing of subsoil use in the practice of constitutional justice. Sud'ia 6: 9-13. (In Russian)

Bogdanov, Dmitrii S., Fionina, Natal'ia P. 2008. Different approaches of substantiating the size of the initial payment for the right to use subsoil. Neft, Gaz i Pravo 5: 23-26. (In Russian)

Bogdanov, Dmitrii S. 2009. Calculation of the sizes of one-off payments for the right to use subsoil plots provided without tenders and auctions. Neft, Gaz i Pravo 5: 27-30. (In Russian)

Denisov, Mikhail N., Lazarev, Valerii N. 2011. On the procedure for determining the starting size of a one-off payment for the use of subsoil. Mineralnie Resursi Rossii. Ekonomika i Upravlenie 2: 41-45. (In Russian)

Dudikov, Mikhail V., Klyukin, Boris D., Melekhin, Evgenii S. 2011. State regulation of subsoil use in the Russian Federation: historical aspect and foreign experience. Moscow, Audit nedropol'zovaniia i konsalting Publ. (In Russian)

Kadomtseva, Anzhelika E. 2013. The legal nature of one-time and regular payments for the use of subsurface resources under Russian law. Zakony Rossii: opyt, analiz, praktika 12: 95-98. (In Russian)

Kozyrin, Aleksandr N. 2015. Legislation in Tax Law: principles of lawmaking procedures. Reformi $i$ pravo 3: 3-13. (In Russian)

Kozyrin, Aleksandr N. 1993. The tax law of foreign countries: questions of theory and practice. Moscow, Manuskript Publ. (In Russian)

Lvov, Dmitrii S. 2003. Perspectives of Long-Term Social and Economic Development of Russia. Vestnik Rossiyskoy Akademii Nauk 8: 675-697. (In Russian)

Orlov, Mikhail Y. 2006. Tax as a form of reasonable limitation of fiscal sovereignty of the state. Finansovoe parvo 2: 18-23. (In Russian)

Perchik, Aleksandr I. 2004. Taxation of oil and gas production. Pravo. Ekonomika. Moscow, Nestor Akademik Publ. (In Russian)

Sutkevich, Elena A. 2015. Payments for the use of subsoil as a form of mandatory public-legal payments similar to taxes and fees. Reformi i pravo 1: 10-13. (In Russian)

Sutkevich, Elena A. 2012. The legal nature of payments for the use of subsoil in the Russian Federation. Reformi i parvo 3: 50-57. (In Russian)

Yalbulganov, Aleksandr A. 2011. On the issue of the transformation of the system of taxes and fees of the Russian Federation. Finansovoe pravo 7: 29-36. (In Russian)

Yanzhul, Ivan I. 2002. Basic Principles of Financial Science: The Study of Government Income. Moscow. (In Russian)

Received: January 9, 2019 Accepted: September 16, 2019

\section{Платежи при пользовании недрами: российский опыт правового регулирования*}

\author{
А. А. Ялбулганов
}

Для цитирования: Yalbulganov A. A. Subsoil use payments: the experience of legal regulation in the Russian Federation // Правоведение. 2018. Т. 62, № 4. С. 779-791.

https://doi.org/10.21638/spbu25.2018.412

Нефтегазовые доходы сохраняют лидирующую позицию в структуре бюджетных доходов. В многообразии платежей за пользование недрами особое место занимают регулярные публично-правовые платежи неналогового характера, закрепленные в Законе

* Статья подготовлена в ходе проведения исследования (проект № 17-01-0064) в рамках Программы «Научный фонд Национального исследовательского университета "Высшая школа экономики" (НИУ ВШЭ)» в 2017-2018 гг. и в рамках государственной поддержки ведущих университетов Российской Федерации «5-100». 
РФ о недрах. На основе анализа законодательства, судебной практики и правовой доктрины исследуется система таких платежей, установленных в Законе РФ о недрах, с точки зрения их правовой природы, качества правового регулирования, а также фискального значения. В связи с дискуссией о необходимости включения неналоговых платежей в текст Налогового кодекса РФ и сферу налогового регулирования автор приходит к выводу о нецелесообразности такого включения. Он объясняет свою позицию рядом объективных причин, прежде всего рентным характером платежей за пользование недрами. В настоящий момент в природоресурсном законодательстве все эти обстоятельства должным образом учтены. В Законе о недрах устанавливаются только минимальные и максимальные ставки платежей, и определяются они в зависимости от видов работ и полезных ископаемых. Конкретный размер ставок устанавливается с учетом поправочных коэффициентов, которые регулярно корректируются Правительством РФ. Вне зависимости от видов платежей за пользование недрами (налоговые или неналоговые платежи) применяются предусмотренные законодательным органом или установленные подзаконными актами корректирующие коэффициенты, которые нацелены на выравнивание экономических условий для недропользователей. Автор отмечает, что неналоговые и налоговые платежи за пользование недрами происходят от одного и того же природного источника - от недр. Вне зависимости от их правовой природы они являются фискальными платежами, доходами от использования недр на разных этапах и поступающими в бюджеты бюджетной системы РФ. Поэтому применительно к регулярным платежам непринципиален факт их включения в систему налогов и сборов Российской Федерация, тем более что администраторами этих платежей выступают налоговые органы. Дополнительными аргументами в пользу фискального характера неналоговых платежей за пользование недрами служит и то, что в Законе о недрах не закреплены природоохранные цели платежей, они не являются целевыми и не поступают в какие-либо государственные внебюджетные фонды. В основании платежей за пользование недрами лежит принцип платности пользования недрами, который применяется при всех видах природопользования и закреплен во всех природоресурсных законах, большинство из которых представляют собой кодифицированные акты. Разовые платежи автор предлагает модернизировать, закрепив все элементы таких платежей непосредственно в законе, а не в правовых актах распорядительного характера, принимаемых по каждому конкретному случаю.

Ключевые слова: платность недропользования; платежи за пользование недрами; недропользователи; разовые и регулярные платежи; соглашение о разделе продукции.

Статья поступила в редакцию 9 января 2019 г;; рекомендована в печать 16 сентября 2019 г.

Ялбулганов Александр Алибиевич - д-р юрид. наук, проф., Национальный исследовательский университет «Высшая школа экономики», факультет права, Российская Федерация, 101000, Москва, ул. Мясницкая, 20; yalbulganov@hse.ru 